Research Article

\title{
Higher Cortisol Level Would Increase the Risk of Spontaneous Abortion
}

\section{Kadar Kortisol yang lebih Tinggi Meningkatkan Risiko Abortus Spontan}

\author{
Christian Sastra, Maria Loho, Joice Kaeng \\ Department of Obstetrics and Gynecology \\ Faculty of Medicine University of Sam Ratulangi \\ Prof. Dr. R.D. Kandou Manado General Hospital \\ Manado
}

\begin{abstract}
Objective: To understand the correlation between cortisol level and spontaneous abortion in normal pregnancy with gestational age less than 20 weeks.

Method: The study design was a correlative analytic prospective study with cross sectional observational approach. This study started from June 2012 until the number of participant sufficiently from Prof. Dr. R.D. Kandou General Hospital. The data then processed SPSS version 2.0, ROC and logistic regression equation model (chance model).

Result: The study included 50 cases consisted of 25 spontaneous abortion cases and 25 normal pregnancies with gestational age less than 20 weeks, and got result if cortisol level for $18.52 \mu \mathrm{g} / \mathrm{dl}$ so spontaneously abortion chance for $35.7 \%$ and if cortisol level for 24.0 $\mu \mathrm{g} / \mathrm{dl}$ would chance for spontaneous abortion for $99.3 \%$.

Conclusion: In this study, there was a significant difference in cortisol level in women with spontaneous abortion and $<20$ weeks normal pregnancy. Higher cortisol level would increase spontaneous abortion risk. The mean cortisol level in spontaneous abortion was $27.28892 \mu \mathrm{g} / \mathrm{dl}$. While the mean cortisol level in women with normal pregnancy was $11.7660 \mu \mathrm{g} / \mathrm{dl}$. Analysis of the correlation between cortisol level and spontaneous abortion gave a cut off point for cortisol level of $19.1 \mu \mathrm{g} / \mathrm{dl}$ with sensitivity of $92 \%$ and specificity of $92 \%$.

[Indones J Obstet Gynecol 2013; 37-1: 17-20]
\end{abstract}

Keywords: cortisol level, normal pregnancy, spontaneous abortion

\begin{abstract}
Abstrak
Tujuan: Mengetahui hubungan antara kadar kortisol pada abortus spontan dengan kehamilan normal pada usia kurangdari 20 minggu.

Metode: Penelitian prospektif analitik korelatif dengan pendekatan cross sectional observational.

Hasil: Penelitian ini melibatkan 50 kasus yang terdiri atas 25 kasus abortus spontan dan 25 kasus kehamilan normal dengan usia kehamilan di bawah 20 minggu yang diukur kadar kortisol serumnya. Penelitian ini dimulai dari Juni 2012 sampai jumlah sampel terpenuhi, di RSUP Prof. R.D. Kandou. Data yang diperoleh kemudian diolah dengan komputer melalui program SPSS versi 20, ROC dan model persamaan regresilogistik (model peluang), dan didapatkan hasil jika kadar kortisol sebesar 18,52 $\mu \mathrm{g} /$ dl maka peluang terjadinya abortus spontan sebesar 35,7\% dan jika kadar kortisol sebesar 24,0 $\mu \mathrm{g} / \mathrm{dl}$ maka peluang terjadinya abortus spontan sebesar 99,3\%.
\end{abstract}

Kesimpulan: Pada penelitian ini didapatkan adanya perbedaan yang bermakna kadar kortisol pada perempuan dengan abortus spontan dan kehamilan normal < 20 minggu. Semakin tinggi kadar kortisol semakin besar risiko terjadinya abortus spontan. Hasil pada penelitian ini kadar rata-rata (mean) kortisol pada abortus spontan didapatkan sebesar 27,2892 $\mu \mathrm{g} / \mathrm{dl}$. Sedangkan pada perempuan dengan kehamilan normal didapatkan rata-rata (mean) $11,7660 \mu \mathrm{g} / \mathrm{dl}$. Hasil analisis hubungan antara kadar kortisol dan kejadian abortus spontan diperoleh cut off point kadar kortisol Sebesar 19,1 $\mu \mathrm{g} /$ dl dan diperoleh nilai sensitivitas sebesar $92 \%$ dan nilai spesifisitas sebesar $92 \%$.

[Maj Obstet Ginekol Indones 2013; 37-1: 17-20]

Kata kunci: abortus spontan, kadar kortisol, kehamilan normal

Correspondence: Christian Sastra. Department of Obstetrics and Gynecology. Faculty of Medicine University of Sam Ratulangi/ Prof. R.D. Kandou Hospital, Manado. Telephone: 0811176951, Fax: 0431-859177. Email: christian_sastra@yahoo.com

\section{INTRODUCTION}

Every family basically hopes to have a good offspring and an excellent descent. This process starts in conception, and continues throughout the pregnancy and parturition. The conception and the beginning of pregnancy (trimester I and II) are important phases, which consist of the implantation of pregnancy product and maintenance of the pregnancy product. Failure of this process can cause spontaneous abortion. Abortion is a term used to describe of termination for every pregnancies before the fetus is viabile, i.e. termination before fetus body weight less than 500 gram. When body weight is unknown, estimation of gestational age before 20 weeks, calculated from date of first day of last menstruation. Spontaneous abortion occurrence in pregnancy $<20$ weeks is an important problems in reproduction. This caused of etiologic of every spontaneous abortion still unknown. ${ }^{1,2}$

The rate of spontaneous abortion is generally about 10 percent from every pregnancy. Another literature mentioned that approximately $15 \%$ to $20 \%$ from all termination of pregnancy is spontaneous abortion. Almost $80 \%$ of spontaneous abortion occurs in the first trimester and the chance will decrease by the increase of gestation age. This 
description result from data has two weakness, were not capable to recognizing early abortion, so the provocative abortion called as spontaneous abortion. ${ }^{1,3}$

In the several first months of gestation, spontaneous expulsion of pregnancy product is almost always preceded with fetal death. Determining the caused of early abortion is an important thing. Generally, the causes of spontaneous abortion are divided into several group: genetic, endocrinology, anatomy, immunology and microbiology. There are also some additional causes for spontaneous abortion, that is infection disease, chronic diseases, abnormalities of endocrine, malnutrition, alcohol abuse, consuming of tobacco, incompetent cervix, immunologic abnormalities and emotional traumatic or even physical traumatic could cause abortion, eventhough the evidence based of its correlation is still not convincing. ${ }^{1,4}$

Cortisol is a dominant glucocorticoid in human being and functioned as an essential component of severe stress. Increasing level of glucocorticoid hormone as a result of diseases or therapeutic measure would cause several serious complications and sometimes can even cause death. One of the complications that can arise because of increasing cortisol in pregnant women is abortion. Study about correlation between abortion and the increasing cortisol level that triggered by stress factors had been done by several researchers i.e. O'Hare and Creed in 1995, and Nepomnaschy in 2006. In the last two decades, studies about environment factors showed that it gives great contribution in causing stress, which in turn could cause endocrine disorders or even immunologic disorders. ${ }^{5-9}$

Stressor stimulated hypothalamus so hypothalamus released CRH (Corticotropin Releasing Hormone) and $\mathrm{CRH}$ stimulating pituitary released ACTH (Adrenocorticotropin hormone). ACTH will stimulate adrenal cortex gland to release cortisol. Based on studies performed by Menasche in 1995 and Nepomnaschy in 2006, increasing of cortisol can caused abortion. Where cortisol in the main component of stress response central. ${ }^{6,10}$

By seeing previously study about factors and risk factor of abortion, where elevating of cortisol level above normal limit is a one risk factor. Further study about elevating of cortisol level as a risk factor to abortion will be necessary. We expect that from this study we could contribute in deciding the actions necessary to prevent abortion.

\section{METHOD}

The study was a cross sectional study. This study was done in Obstetrics and Gynecology Department, Faculty of Medicine, University of Sam Ratulangi/Prof. Dr. R.D. Kandou General Hospital from June 2012 until the required number of sample fulfilled.

We established a group of pregnant women who suffered spontaneous abortion and other group of normal pregnant women with gestational age less than 20 weeks as a control, from patients who came to Prof. Dr. R.D. Kandou Manado General hospital. Patient who fulfilled inclusion criteria and agreed to joint the study was then asked to sign informed consent after given explanation about the objective and aim of study. Blood sample was taken from patient before curettage. The sample was carried out in Prodia laboratory for centrifugation and then sent to Centre laboratory of Prodia in Jakarta to be examined for its cortisol level. The laboratory result then was analyzed.

\section{RESULTS}

The characteristic of the subjects in both groups was described in Table 1 . Most of the study participant was multiparity, both in women with spontaneous abortion $(60.0 \%)$ and women with normal pregnancy (52.0\%). Most study subjects in the cases group were in 25-29 years old group $(40.0 \%)$, while the subjects in the control group were mostly in the 20-24 years old or 30-34 years old group (28.0\% each). Most subjects graduated from senior high school both in the case group $(48.0 \%)$ and the control group (32.0\%). Most subjects in the case group were entrepreneurs $(36.0 \%)$, while in the control group, most subjects were housewives (56.0\%).

Table 1. Participant characteristic based on number of parity

\begin{tabular}{ccccc}
\hline \hline Parity & $\begin{array}{c}\text { Spontaneous } \\
\text { Abortion }(\mathbf{n}=\mathbf{2 5})\end{array}$ & $\begin{array}{c}\text { Normal pregnancy } \\
\text { with gestation age } \\
\text { less than 20 } \\
\text { weeks (n = 25) }\end{array}$ \\
\cline { 2 - 5 } & $\mathbf{n}$ & \% & n & \% \\
\hline Prime parity & 10 & 40.0 & 12 & 48.0 \\
Multi parity & 15 & 60.0 & 13 & 52.0 \\
\hline Total & 25 & 100 & 25 & 100 \\
\hline \hline
\end{tabular}


Table 2. Correlation between the cortisol level with spontaneous abortion occurrence

\begin{tabular}{lccc}
\hline \hline \multicolumn{1}{c}{ Model } & Coefficient & p & Mean \\
\hline Cortisol level & 1.032 & 0.008 & Significant \\
Constant & -19.693 & 0.009 & \\
\hline \hline
\end{tabular}

The mean level of cortisol in spontaneous abortion group was $27.29 \mu \mathrm{g} / \mathrm{dl}$, while the mean level in the group of women with normal pregnancy was $11.77 \mu \mathrm{g} / \mathrm{dl}$. Table 2 describes the correlation between cortisol level and the occurrence of spontaneous abortion. The graphic could be seen in Figure 1. This shows that the higher of cortisol level, the higher the risk for spontaneous abortion to occur.

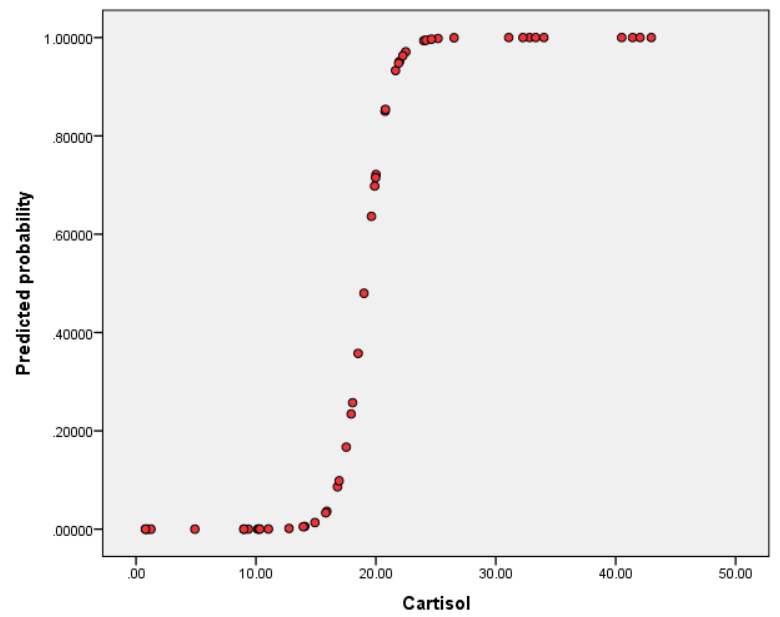

Figure 1. Correlation between level of cortisol and chance of spontaneous abortion in women.

Based on the logistic regression analysis result, we acquire the cut off point level of cortisol was $19.1 \mu \mathrm{g} / \mathrm{dl}$ with sensitivity of $92.0 \%$ and specificity of $92.0 \%$.

\section{DISCUSSION}

This study used spontaneous abortion patient as cases and normal pregnancy women with gestation age less than 20 weeks as control. This study used the theory that has been described by Menashe in 1995 that elevated cortisol level could cause abortion. ${ }^{10,11}$

Based on literature showed that multi gravid for 15 cases or $60.0 \%$ compared with prime gravid for 10 cases or $40 \%$ that can be saw in Table $1 .^{12}$
There was a significant correlation between cortisol level with the chance of spontaneous abortion. If cortisol level was $18.52 \mu \mathrm{g} / \mathrm{dl}$ the chance for spontaneous abortion was $35.7 \%$ and if cortisol level was $24 \mu \mathrm{g} / \mathrm{dl}$, the chance for spontaneous abortion was $99.3 \%$. Several studies had proven that there is correlation between higher level of cortisol with spontaneous abortion. A study that has been done by Nepomnaschy in 2004 on 22 pregnant women found that from 13 cases spontaneous abortion the cortisol level increased in 9 cases, while 4 another cases has normal cortisol level.

In this study, the mean level of cortisol in spontaneous abortion group was $27.29 \mu \mathrm{g} / \mathrm{dl}$, while the mean level in the group of women with normal pregnancy was $11.77 \mu \mathrm{g} / \mathrm{dl}$. This result is similar with the result from other studies. For example the study performed by Goland in 1994 where in normal pregnant women, only $5-15 \%$ had a higher cortisol level, whereas in the abortion cases, $40 \%$ of the subjects had a higher cortisol level..$^{13}$ There is a no clear explanation as to why in some women with normal pregnancy, the higher level of cortisol doesn't automatically end in abortion. This maybe because abortion is not only affected by endocrine factors, nut immunological factors as well, as explained by Pinto Natasya in his study that higher level of cortisol would great influences to Th1 (T helper 1) and Th2 (T helper 2) balance can caused of abortion. ${ }^{14}$

\section{CONCLUSION}

There is a significance difference of cortisol level in women with spontaneous abortion and normal pregnancy less than 20 weeks. Higher level of cortisol increases the risk spontaneous abortion risk. The cut off point of cortisol level to predict spontaneous abortion is $19.1 \mu / \mathrm{dl}$ with sensitivity of $92 \%$ and specificity of $92 \%$.

\section{REFERENCES}

1. Cunningham FG, Leveno KJ, Bloom SL, Hauth JC, Rouse DJ, Spong CY. Abortion in Williams Obstetrics, 23 ${ }^{\text {rd }}$ Ed, McGraw Hill Comp. 2010; 9: 215-37

2. Speroff L, Fritz MA. The Endocrinology of Pregnancy in Clinical Gynecologic Endocrinology and Infertility, $7^{\text {th }}$ edition, Lippincott Williams and Wilkins, Philadhelphia. 2005: 8 
3. Stoval TG, Berek JS, Rinehart RD, Hengst TC, Seigafuse S, Dernoski NT. Early Pregnancy Loss and Ectopic Pregnancy in Berek. JS, Novak's Gynecology, 14th Edition, Lippincott William and Wilkins Company. 2007: 18

4. McNair T, Altman K. Miscarriage and Recurrent Pregnancy Loss in The Johns Hopkins Manual of Gynecology and Obstetrics, $4^{\text {th }}$ edition, Lippincott Williams and Wilkins, Philadelphia. 2011: 438-53

5. Arck CP, Rose M, Hertwig K, Hildebrandt M, Klapp FB. Stress and immune mediators in misscarriage. J Hum Reprod. 2001; 16(7): 1505-11

6. Nepomnaschy PA, Kathleen B. Cortisol levels and very early pregnancy loss in humans. Diakses dari: www.pnas.org/ content/103/10/3938.full.pdf pada tanggal 15 Januari 2012

7. Matsubayashi H, Takashi H, Shun-ichiro I, Takahiro S. Emotional distress of infertile women in Japan. J Hum Reprod. 2001; 16(7): 1505-11

8. Sasaki A, Shinkawa, and Yoshinaga K. Placental corticotrophin-releasing hormone may be a stimulator of maternal pituitary adrenocorticotrophin hormone secretion in human, J. Clin. Invest. 1999; 84: 1997-2001
9. O'Hare T, Creed F. Life events and miscarriage. Bri J Psych. 1998; 167: 799-805

10. Menashe Y, Bider D, Shalev J, Pariente C, Serr D.M. Clinical, hormonal and sonographic predictors of successful RU-486induced abortions. Gynecol Obstet Invest. 1995; 40(2): 10812

11. Chrousos G.P. Regulation and dysregulation of the hypothalamic-pituitaryadrenalaxia. The corticotrophin-releasing hormon perspective. Endocrinol Metab Clin. 1992; 21: 83359

12. Berghella M. Recurrent Pregnancy Loss. In Obstetrics Evidence Based Guidelines, $2^{\text {nd }}$ edition. Informa Healthcare. 2012: 14

13. Goland, S Robin. Fetus-Placenta-Newborn: Placental Coriocotrophin-Releasing Hormone and the Hypercorticolism of Pregnancy, Am J Obstet Gynecol. 1994; 171: 1287-91

14. Bonari L, Natasha P. Perinatal Risk of Untreated Depression During Pregnancy, Can J Psychiatry. 2004; 49: 726-35 